\title{
Zakat Management Paradigm: Comparison of Indonesia, Malaysia, and Saudi Arabia
}

\author{
Muhammad Anwar Fathoni, Suryani, Eko Nur Cahyo \\ Universitas Pembangunan Nasional Veteran, Jakarta, Indonesia \\ IAIN Malikussaleh Lhokseumawe, Aceh, Indonesia \\ Coventry University, United Kingdom \\ mfathoni@upnvj.ac.id,suryapijar@yahoo.com,ekonuralmalowy@gmail.com
}

\begin{abstract}
The obligation of Muslims in performing zakat is expected to deal with the problem of income distribution among human beings. This article aims to find out the management of zakat in three Muslim countries, Indonesia, Malaysia and Saudi Arabia. Significant findings resulted there are differences in the management of zakat in Indonesia, Malaysia and Saudi Arabia. From the side of the law it is known that Indonesia and Malaysia do not require zakat in their laws, but they are different from Arab Saudi that has been developed an online-based zakat collection and tax system. While from the zakat collection system, the policy in Malaysia makes zakat a tax deduction.
\end{abstract}

Keywords: comparative study, management system, zakat management, zakat regulation.

Permalink/DOI: bttps://doi.org/10.18326/infsl3.v14i2. 267-282 


\section{Introduction}

Islam is a perfect religion. The perfection of Islam is seen and known in all the rules aimed at the people. These rules cover all aspects of human life related to worships, politics, social life, and economy. The existence of these rules is not to curb humanity but they are created for the human's guidelines for their lives; therefore, they do not do any damages on earth.

In Islam, there are Islamic pillars which are comprising five main obligations of a Muslim. The pillars of Islam which consist of reciting the shahada, prayer, fasting, almsgiving and going on pilgrimage if you are able must really be practiced by every Muslim. If there is one pillar is not being implemented, then one's Islam can be questioned.

Zakat is one of the pillars of Islam, that must be carried out by all Muslims (Kashif et al., 2018). Zakat is derived from the Arabic word $a z-z a k a a b$ which is the masdar form of Zakaa. Zakaa itself is a form of Fi'il Madhi which means to grow, grow and develop. Whereas according to the term zakat is a treasure that must be issued by Muslims within a certain time and given to certain groups (Ridwan, 2016).

Zakat is a worship that has multiple benefits, it is called as spiritual benefits for people who pay zakat (muzakki) and social benefits for people who receive zakat (mustahik). People who pay zakat will feel a calm and a comfort soul because it has fulfilled Allah's orders. Whereas those who receive zakat will feel pleasure because their economy has been helped by those who give zakat (Muzakki) (Abdullah et al., 2015; Mikail et al., 2017)namely, the Basic Needs Deficiency Index (BNDI. 
Based on the language understanding, the concept of wealth spent on zakat will grow and develop because of the prayers of those who receive it. Zakat is essentially a waste of property that must be disposed of by muzakki so that the property is free from doubtfulness so that it can purify all of the muzakki's assets (Mikail et al., 2017).

Zakat is one of the social instruments in Islam that is used for economic equality. The obligation of every Muslim to issue zakat is a humanistic aspect of this teaching. The distribution of income needs to be arranged so that assets are not concentrated in certain parties (Saad \& Foori, 2020).

If it is judged from the management of zakat in the time of the Prophet, zakat can be a meaningful solution to reduce poverty in various countries. In mustahik zakat, there are two main groups come from the weak and unable, namely the needy and the poor (Ahmed et al., 2017). If the collection and distribution of zakat is carried out appropriately and optimally, the poverty rate can drop quite dramatically (Mochlasin, 2018). Therefore, it will have an impact on increasing a country's national income which develops the country's welfare.

In the management of zakat there are amil zakat institutions which function as zakat collectors, managers and distributors. These institutions can come from the government or the community (Abdurahim et al., 2018)namely Lazis Based on Islamic Organization $\mathrm{X}$ and Rumah Zakat in complying requirements as a good governance Lazis, with reference to Religion Ministerial Decree (Keputusan Menteri Agama/KMA. Each country has differences in managing zakat. It all depends on the policies of each country. 
In this paper, we will explore the comparison of three Muslim countries in managing zakat and the comparison in zakat institutions, they are Indonesia, Malaysia and Saudi Arabia. Besides, it will also discuss the influence of the presence of zakat institutions in each country on poverty rates in these countries.

\section{Methods}

The methodology used in this study was qualitative research. The secondary data which cover the paradigm of zakat management in three different countries, including Indonesia, Malaysia, and Saudi Arabia. The method employed in this paper is content analysis to concern on the ideas related to the particular pattern of three countries above in managing zakat and dealing with the impact of zakat on the poverty and social problem in each country.

\section{Result and Discussion}

\section{Management of Zakat in Indonesia}

Indonesia is a country with the largest Muslim population in the world. A large number of Muslims in this country raises the massive potential of zakat. It is estimated, the potential for zakat in Indonesia is 217 trillion rupiah (S. Alam, 2019). Unfortunately, from the potential of that size, the collected zakat is only 4 trillion rupiahs, approximately $4 \%$ of the available zakat potential (Budianto, 2019). Then in terms of the distribution of zakat an average of $66.03 \%$ of the amount of zakat collected.

The development of zakat management institutions in Indonesia is divided into five phases, namely: (1) The first phase, the management of zakat has been going on since colonialism. During this period, the colonial government tried to prevent the management of zakat from being individualized. The reason is that there are allegations that the zakat funds were used to finance resistance to the colonial government. (2) The second phase during the reign of the old order, which lasted from 1945 to 1967, the management of zakat no longer gets obstacles from the government. But at this time the management of zakat funds is still carried out individually. (3) The third phase has occurred during the reign of the new order, which took place from 1968-1998. The zakat has received a consideration 
from the community so that zakat management institutions have emerged, the government has also paid attention to the zakat sector although it has not yet reached the targetted level; issuance of formal laws. (4) The fourth phase is a transition period that started from 1999 to 2000. In this period, the Law on the Management of Zakat Number 28 of 1999 was enacted. The emergence of this law led to the birth of many local regulations on zakat management. (5) The fifth phase that occurred in the reformation era (2001-present) The development of zakat institutions is relatively rapid, and several other regulations regarding zakat and its management are present (K., 2015).

In Indonesia, there are three types of zakat management organizations (OPZ), namely the Amil Zakat Agency (BAZ) and the Amil Zakat Institution (LAZ) and the Zakat Collecting Unit (UPZ). LAZ is OPZ which is formed by the community. Whereas UPZ is an organization formed by BAZNAS (Indonesia, 2011).

\section{Amil Zakat Agency (BAZ)}

BAZ is an OPZ formed by the government. The task of BAZ is to collect, distribute and utilize zakat. In addition to managing zakat, BAZ also manages infaq, shadaqah and other social funds. BAZNAS is the name of BAZ Indonesia. BAZNAS has the zakat management which covers for the national level. BAZNAS is domiciled in the national capital and is structural. BAZNAS is independent and is responsible to the president through the minister. BAZNAS consists of eleven members. The components in BAZ consist of not only the governmentbut also the community. Community membership includes scholars, Islamic community leaders and professional staff and Muslim community leaders (Baznas, 2020).

There is a BAZNAS that manages zakat based on provincial and district/city levels. The provincial-level BAZNAS was formed by the Minister of Religion Affairs and is assigned to manage zakat funds at the provincial level. At the same time, the BAZNAS district/ city level was formed by the Director-General of Islamic Guidance and is appointed to manage zakat funds at the district/city level (Baznas, 2020). Recently, there are 34 BAZNAS at the provincial level and 500 BAZNAS at the city level (Baznas, 2020). The formation of 
both aims to facilitate the performance of BAZNAS in collecting, distributing and utilizing zakat funds, so that people who live far from the capital can still distribute their zakat through this government agency. Each level of BAZNAS ranging from national to city is coordinative, consultative and informative (Ridwan, 2016).

BAZNAS carries out its work by creating work programs. The BAZNAS work program is divided into five program areas, namely education, economics, religion, health and social. There are two characteristics of these programs, namely short term and long term. Short-term plans are used to distribute zakat in the consumptive sector. In contrast, the long-term program is in the form of utilizing zakat funds to empower the community (Fadillah et al., 2017).

Table 1. Receipt and distribution of BASNAZ zakat funds in 2016, 2017 and 2018

\begin{tabular}{ccccr}
\hline Time & Reception & \multicolumn{2}{c}{ Distribution } \\
\hline 2016 & $\mathrm{Rp}$ & 97.637 .657 .910 & $\mathrm{Rp}$ & 67.727 .019 .807 \\
2017 & $\mathrm{Rp}$ & 138.096 .290 .551 & $\mathrm{Rp}$ & 118.071 .046 .770 \\
2018 & $\mathrm{Rp}$ & 195.092 .051 .942 & $\mathrm{Rp}$ & 175.811 .470 .985 \\
\hline \multicolumn{3}{c}{ Source: BAZNAS Financial Report } \\
bttps://baznas.go.id/
\end{tabular}

Based on the data above (table 1) we can see that during the last three years the receipt and distribution of zakat funds has increased. This is a sign that Indonesian people have begun to care about the importance of zakat. In addition, this also indicates that the performance of BAZNAS is increasing.

Amil Zakat Institution (LAZ)

LAZ is an OPZ formed and managed by the community and must obtain permission from the Minister or an official appointed by the Minister. Like BAZ, LAZ also manages infaq, shadaqah and endowment funds in addition to managing zakat funds. In its operational activities, LAZ is required to report on the collection, distribution and utilization of zakat funds to the audited BAZNAS periodically (Permana \& Baehaqi, 2016)journal articles or other literature based on the topic being discussed. The results of this study show that good governance is required by LAZ to improve professional performance 
in order to meet the interests of stakeholders. The implementation of Good Governance Principles in the management of zakat is as follows: Transparency, it means that LAZ must apply the principle of information disclosure to stakeholders. Accountability, it means that LAZ must hold the principle of trust (accountable.

There are four classifications of LAZ, namely: (1) LAZ which is mosque based. LAZ was established because of the rapid development of the mosque so that it creates trust in the community that drives the formation of LAZ. Examples of this LAZ are LAZ Al Azhar Cares (Al Azhar Mosque), LAZ Salman Charity House (Salman Mosque ITB) and LAZ DPU-DT (Daarut Tauhid Mosque). (2) LAZ based on Community Organizations (Ormas). LAZ was founded by community organizations aimed at increasing the role of CSOs in society. LAZ included in this sector are LAZ Muhammadiyah, LAZ NU, and LAZ Center for Zakat Umat (Mass Organizations). (3) LAZ based company. In general, the formation of LAZ is due to a company wanting to carry out Corporate Social Responsibility (CSR). The management of CSR funds that is quite large makes the company needs a trustworthy and professional institution. From there, the forerunner to the formation of this group LAZ. Among LAZ included in this group are Baitul Maal Muamalat (Bank Muamalat Indonesia), Baitul Maal BRI (Bank Rakyat Indonesia), and LAZ Baitul Maal Muttaqien (PT Telkom). (4) LAZ based as OPZ. LAZ from its inception was intended to be amil zakat. Examples include Dompet Dhuafa, LAZ Rumah Zakat Indonesia and LAZ Rumah Yatim Arrohman (Fadillah et al., 2017).

Table 2. LAZ Description Based on the Group

\begin{tabular}{lllll}
\hline & $\begin{array}{c}\text { Mosque } \\
\text { based }\end{array}$ & $\begin{array}{c}\text { Communi- } \\
\text { ty Based }\end{array}$ & $\begin{array}{c}\text { Company } \\
\text { Based }\end{array}$ & $\begin{array}{c}\text { Based on } \\
\text { OPZ }\end{array}$ \\
\hline Zakat & 1. Muzaki & 1. Muzaki is & 1. Muzaki is & Muzaki is \\
Collec- & mainly & the main & based pri- & primarily \\
tion De- & comes & member & marily on & from the \\
sign & from & of the & employees & wider \\
& mosque & mass or- & 2. Wide Com- & community \\
& worshipers & ganization & munity & \\
& 2. Wide & 2. Wide & & \\
Commu- & Commu- & & \\
& nity & nity & &
\end{tabular}




\begin{tabular}{|c|c|c|c|c|}
\hline & $\begin{array}{c}\text { Mosque } \\
\text { based }\end{array}$ & Communi- & $\begin{array}{c}\text { Company } \\
\text { Based }\end{array}$ & $\begin{array}{c}\text { Based on } \\
\text { OPZ }\end{array}$ \\
\hline $\begin{array}{l}\text { Zakat } \\
\text { Empow- } \\
\text { erment } \\
\text { Design }\end{array}$ & $\begin{array}{l}\text { 1. Intend- } \\
\text { ed for } \\
\text { mosque } \\
\text { worship- } \\
\text { ers Wide } \\
\text { Commu- } \\
\text { nity }\end{array}$ & $\begin{array}{l}\text { 1. Intend- } \\
\text { ed for } \\
\text { members } \\
\text { of mass } \\
\text { organiza- } \\
\text { tions } \\
\text { 2. Wide } \\
\text { Commu- } \\
\text { nity }\end{array}$ & $\begin{array}{l}\text { 1. Intended } \\
\text { for employ- } \\
\text { ees in need } \\
\text { 2. Wide Com- } \\
\text { munity }\end{array}$ & $\begin{array}{l}\text { Intended } \\
\text { for musta- } \\
\text { hik from the } \\
\text { wider com- } \\
\text { munity }\end{array}$ \\
\hline $\begin{array}{l}\text { Design } \\
\text { of Con- } \\
\text { sumer } \\
\text { Rela- } \\
\text { tions }\end{array}$ & $\begin{array}{l}\text { Alignedwith } \\
\text { programs that } \\
\text { have been } \\
\text { made by } \\
\text { DKM Masjid, } \\
\text { delivery of } \\
\text { information } \\
\text { with elec- } \\
\text { tronic media, } \\
\text { print media, } \\
\text { and others. }\end{array}$ & $\begin{array}{l}\text { Aligned with } \\
\text { social organi- } \\
\text { zations pro- } \\
\text { grams such } \\
\text { as social ser- } \\
\text { vices, study, } \\
\text { delivery of } \\
\text { information, } \\
\text { with print } \\
\text { media, elec- } \\
\text { tronic media, } \\
\text { and others.. }\end{array}$ & $\begin{array}{l}\text { Harmonious } \\
\text { with company } \\
\text { policies such } \\
\text { as the rules } \\
\text { that apply to } \\
\text { all employees, } \\
\text { delivery of } \\
\text { print media, } \\
\text { electronic me- } \\
\text { dia, and oth- } \\
\text { ers.. }\end{array}$ & $\begin{array}{l}\text { 1. Activities } \\
\text { are made } \\
\text { accord- } \\
\text { ing to the } \\
\text { needs / } \\
\text { requests } \\
\text { of muzaki } \\
\text { 2. Submis- } \\
\text { sion of in- } \\
\text { formation } \\
\text { through } \\
\text { various } \\
\text { media that } \\
\text { can be ac- } \\
\text { cessed by } \\
\text { the wider } \\
\text { commu- } \\
\text { nity }\end{array}$ \\
\hline $\begin{array}{l}\text { Program } \\
\text { Creation } \\
\text { Design }\end{array}$ & $\begin{array}{l}\text { 1. ombined } \\
\text { with DKM } \\
\text { Mosque } \\
\text { adapted } \\
\text { to the } \\
\text { needs of } \\
\text { mustahik } \\
\text { around the } \\
\text { mosque }\end{array}$ & $\begin{array}{l}\text { 1. Combined } \\
\text { with com- } \\
\text { munity } \\
\text { organi- } \\
\text { zations } \\
\text { adapted to } \\
\text { the needs } \\
\text { of musta- } \\
\text { hik }\end{array}$ & $\begin{array}{l}\text { 1. Combined } \\
\text { with the } \\
\text { company's } \\
\text { CSR pro- } \\
\text { gram } \\
\text { 2. Adapted to } \\
\text { the musta- } \\
\text { hik needs } \\
\text { of LAZ's } \\
\text { target }\end{array}$ & $\begin{array}{l}\text { Designed } \\
\text { according } \\
\text { to the needs } \\
\text { of mustahik } \\
\text { and muzaki } \\
\text { based on } \\
\text { thorough re- } \\
\text { search }\end{array}$ \\
\hline
\end{tabular}

Sources: Fadilah, Lestari, and Rosdiana, "Zakat Management Organization (OPZ): Description of Zakat Management from Zakat Institution Aspects." 
The development of LAZ in Indonesia is growing rapidly. Currently, there have been 18 National LAZs that have received permission from the government (Baznas, 2020). Besides, there are still many zakat institutions that are waiting in line to get permission from the government. This is a good signthat LAZ has gained trust in the community. Through LAZ, it is expected that the Indonesian people will get a better education so that the potential for zakat can be channelled to the fullest range of them.

Table 3. Receipt and Distribution of Zakat funds through LAZ

\begin{tabular}{|c|c|c|}
\hline Time & Reception & Distribution \\
\hline 2017 & Rp 2.195.968.539.189 & Rp 1.710.481.136.382 \\
\hline 2016 & Rp 1.401.248.170.005 & Rp 1.163.861.023.514 \\
\hline 2015 & Rp 2.208.193.434.453 & Rp 1.262.130.957.632 \\
\hline
\end{tabular}

Based on the table 3 above, the number of zakat receipts decreased in 2016. But in 2017, there was an increase in zakat receipts. This indicates that LAZ experienced a fluctuation in the receipt of zakat. The acceptance of zakat will affect the distribution of zakat. The distribution of zakat will decrease if its acceptance decreases and vice versa, the distribution of zakat will increase if the revenue increases.

\section{Zakat Collecting Unit (UPZ)}

UPZ is a zakat institution formed by BAZNAS to help the collection of zakat funds (Mustahal \& Kelib, 2017). In managing the zakat fund, the UPZ area covers sub-districts and villages. So, funds from UPZ will go to the BAZNAS zakat report because UPZ is basically part of BAZNAS. UPZ can be formed in government agencies, BUMN, BUMD, universities, mosques and also private institutions. With the existence of UPZ, it can help people who want to fulfil their obligations on zakat (Intan, 2018).

UPZ has increased in terms of zakat receipts and in terms of the number of UPZ. In October 2018, UPZ had collected zakat funds of IDR 50 billion. At present, there are $128 \mathrm{UPZ}$ formed in 
the institutions mentioned above (Intan, 2018). Hopefully, UPZ can continue to grow so that more people will be helped since their adulthood. Based on the description of the three amil zakat institutions above, we can know that in Indonesia zakat management can be carried out by two parties, namely the government through BAZNAS and UPZ and the community through LAZ. Through the data above, LAZ raised more funds than BAZ and UPZ. Funds received and disbursed by LAZ reached trillions of rupiah. While the zakat funds collected and distributed by BAZ and UPZ only range in the billions of rupiah. One factor that causes the receipt and distribution of zakat funds in BAZ is smaller than LAZ is the lack of innovative BAZNAS. BAZNAS still often uses conventional methods. Whereas LAZ has innovated by making competitive products with the aim to attract public trust. Then in the management of zakat, the public believes more in LAZ because it is more accountable and transparent in its distribution (Niam, 2016). Transparency and accountability are very important so that zakat institutions can attract more muzaki. That will encourage an increase in the amount of zakat receipts which will then impact on poverty reduction.

In Indonesia, zakat is only used as a religious obligation for every individual who is Muslim. There are no regulations that specifically emphasize the obligation to pay zakat for all Indonesian citizens who are Muslim. This happens because Indonesia is a country that does not use Islamic law in the implementation of its state administration. As a result, zakat is only paid by Muslims according to the consciousness of each individual. Besides, other impacts arising in the form of a lack of education in Indonesian Muslim communities about zakat so that the potential for zakat is not maximally distributed. This of course makes us all sad (A. Alam, 2018). How can a country that is predominantly Muslim actually not have enough education about zakat? This is the duty of all parties. Both BAZNAS, LAZ, and UPZ must work together in hand to hand to optimize the collection and distribution of zakat. The three institutions must work together in harmony to create an Indonesian state that has a developed economy.

Management of Zakat in Malaysia

Malaysia is a country with a Muslim majority population. In contrast 
to Indonesia, Malaysians have a high awareness of paying zakat. Not only zakat fitrah, Malaysian population education about zakat maal is also quite good. Therefore, the development of zakat institutions in Malaysia is relatively rapid. Coupled with support from the government for amil zakat institutions managed by the community makes Malaysia a good country to be an example in the management of zakat (Suprayitno et al., 2017).

In Malaysia, the collection of zakat funds is carried out by institutions managed by the private sector in each state. This makes the collection of zakat not be done centrally. The zakat institution is in the form of a private zakat institution and Baitul Maal or a power of attorney under the State Islamic Council. The role of the government,in this case, is only as a facilitator and person in charge of the zakat institution (Saad \& Foori, 2020).

The Malaysian Islamic Council (MAI) coordinates with non-department ministries in the management of zakat. Through MAI was born the Zakat Collection Center (PPZ) which officially operated on January 1, 1991. PPZ was established in the Kuala Lumpur alliance, as well as five states including Melaka, Pahang, Selangor, Pulau Pinang and Negeri Sembilan. In the same time, eight other states perform the function of collecting zakat in Baitul Maal (BM). There is one interesting policy about zakat in Malaysia (K., 2015). The policy is to make zakat a tax deduction. This policy made Malaysia apply zakat as a semi-monetary policy instrument (table 4).

Table 4. Acceptance of Zakat in Malaysia in 2018, 2017 and 2016

\begin{tabular}{lrrr}
\hline Type of Zakat & \multicolumn{1}{c}{$\mathbf{2 0 1 8}$} & $\mathbf{2 0 1 7}$ & \multicolumn{1}{c}{$\mathbf{2 0 1 6}$} \\
\hline Zakat Revenue & $445,442,587.94$ & $408,848,038.25$ & $392,446,919.06$ \\
Commercial & $118,140,629.41$ & $122,142,889.95$ & $106,304,269.21$ \\
Zakat & $45,951,227.27$ & $42,812,531.38$ & $39,328,135.04$ \\
Zakat Deposits & $777,187.41$ & $1,071,490.83$ & $39,606,805.24$ \\
Qadha Zakat & $38,032,627.71$ & $37,745,826.00$ & $432,984.45$ \\
Zakat Mal (Trea- & & $2,578,331.65$ & $2,571,047.84$ \\
sure) & $2,883,773.20$ & & \\
Other Alms & & &
\end{tabular}




\begin{tabular}{lccc}
\hline Type of Zakat & $\mathbf{2 0 1 8}$ & $\mathbf{2 0 1 7}$ & $\mathbf{2 0 1 6}$ \\
\hline $\begin{array}{l}\text { Number of Cita- } \\
\text { tions }\end{array}$ & $651,228,032.94$ & $615,199,108.06$ & $580,690,160.84$ \\
\hline
\end{tabular}

Source: Statistics of Quotes \& Payers of Zakat PPZ-MAIWP 2018, 2017 and 2016

\section{Management of Zakat in Saudi Arabia}

In Saudi Arabia, the collection of zakat is carried out together with taxes by the government through the Ministry of Finance. Therefore, an institution called the Department of Zakat and Income Tax (Mashlahah az-Zakaah Wa ad-Dakhl) was formed. Before 1951, Saudi Arabia did not yet have a law regarding zakat management. Then in $1951 \mathrm{AD}$ was enacted a law regarding zakat management based on the King's Decree (Royal Court) No. 17/2/28/8634 on April 7, 1951 AD $(29 / 6 / 1370 \mathrm{H})$ which stipulated the obligatory zakat system (zakat syar'i). From this decision it was determined that the management of zakat was carried out based on Islamic law. Then, for individuals and companies who are citizens of Saudi Arabia are required to pay zakat (Ridwan, 2016). Whereas for citizens who are citizens of non-Saudi Arabia only subject to income tax (Sulistiani, 2016). Furthermore, there are regulations that allow individuals to distribute their own zakat, and the rest is distributed to the Department of Zakat and Income Tax institutions. As for companies, zakat is distributed entirely to the Department of Zakat and Income Tax (Muhammad, 2019).

Zakat collection in Saudi Arabia applies to all types of assets. There is a commission called Al-Awamil under coordination between the Ministry of Finance and the Ministry of the Interior. The Al-Awamil Commission is tasked with collecting zakat from the types of agricultural alms, trade alms, alms deposits, and alms income to remote areas. In terms of zakat distribution, the authorized institution is the Ministry of Social Affairs and Work under the Director-General of Social Security (Sawmar \& Mohammed, 2019).

Saudi Arabia has developed an online-based zakat collection and tax system. The Department of Zakat and Income Tax has a complete database and is supported by ICT (Information and Communication Technology) devices. This makes Saudi Arabia a coun- 
try that is classified as advanced in the management of zakat (Altawyan, 2020).

\section{Conclusion}

To conclude this paper, that only Saudi Arabia requires zakat and has a legal umbrella. Unlike Indonesia and Malaysia, which do not require their people to issue zakat in their laws. It can be acknowledged that the management of zakat in Saudi Arabia is directly regulated by the government. Meanwhile, Malaysia does not require zakat in its laws which consequently is the management of zakat in Malaysia handed over to the private sector. Likewise with Indonesia which does not require zakat in its laws, but the difference lies in the management of zakat which is carried out by the State and the private sector simultaneously. 


\section{References}

Abdullah, N., Derus, A. M., \& Al-Malkawi, H. A. N. (2015). The effectiveness of zakat in alleviating poverty and inequalities a measurementusing a newly developedtechnique. Humanomics, 31(3), 314-329. https://doi.org/10.1108/H-02-2014-0016

Abdurahim, A., Sofyani, H., \& Wibowo, S. A. (2018). Membangun Good Governance di Lembaga Amil Zakat, Infaq dan Shadaqah (LAZ): Pengalaman Dua LAZ Besar di Indonesia. INFERENSI: Jurnal Penelitian Sosial Keagamaan, 12(1), 45-64. https://doi. org/10.18326/infsl3.v12i1.45-64

Ahmed, B. O., Johari, F., \& Wahab, K. A. (2017). Identifying the poor and the needy among the beneficiaries of zakat Need for a zakat-based poverty threshold in Nigeria. International Journal of Social Economics, 44(4), 446-458. https://doi. org/10.1108/IJSE-09-2015-0234

Alam, A. (2018). Permasalahan dan solusi pengelolaan zakat di Indonesia. Jurnal Manajemen, 9(2), 128. https://doi. org/10.32832/jm-uika.v9i2.1533

Alam, S. (2019). Menteri PPN : Potensi Zakat di Indonesia Capai Rp217 Triliun. Rri.Co.Id. http://rri.co.id/post/berita/644845/ ekonomi/menteri_ppn_potensi_zakat_di_indonesia_ ca\%0Apai_rp217_triliun.html.

Altawyan, A. A. (2020). The tax and zakat appeal system in the Kingdom of Saudi Arabia: An overview. Journal Sharia \& Law. https://ssrn.com/abstract $=3577998$

Baznas. (2020). Profil BAZNAS RI. https://baznas.go.id/profil

Budianto, A. (2019). Ratusan Triliun Potensi Zakat di Indonesia Belum Tergarap Maksimal. SINDOnews.Com,. https://jabar. sindonews.com/read/6954/1/ratusan-triliun-\%0Apotensizakat-di-indonesia-belum-tergarap-maksimal-1557151547.

Fadillah, S., Lestari, R., \& Rosdiana, Y. (2017). Organisasi Pengelola Zakat (OPZ): Deskripsi Pengelolaan Zakat Dari Aspek Lembaga Zakat. Kajian Akuntansi, 18(2), 148-163. https:// ejournal.unisba.ac.id/index.php/kajian_akuntansi/article/ 
download/3085/1927

Indonesia, U.-U. R. (2011). Undang-undang nomor 23 tahun 2011 tentang pengelolaan zakat. https://kalteng.kemenag.go.id/ file/file/GONDO/5121567496646.pdf

Intan, N. (2018). Baznas Prediksi UPZ 2018 Capai Rp 63 Miliar. Republika Online. https://republika.co.id/share/ph33ka423

K., Amiruddin (2015). Model-Model Pengelolaan Zakat Di Dunia Muslim. Abkam: Jurnal Hukum Islam, 3(1). https://doi. org/10.21274/ahkam.2015.3.1.137-164

Kashif, M., Faisal Jamal, K., \& Abdur Rehman, M. (2018). The dynamics of Zakat donation experience among Muslims: a phenomenological inquiry. Journal of Islamic Accounting and Business Research, 9(1), 45-58. https://doi.org/10.1108/ JIABR-01-2016-0006

Mikail, S. A., Ahmad, M. A. J., \& Adekunle, S. S. (2017). Utilisation of zakah and waqf fund in micro-takaful models in Malaysia: an exploratory study. In ISRA International Journal of Islamic Finance (Vol. 9, Issue 1, pp. 100-105). https://doi.org/10.1108/ IJIF-07-2017-010

Mochlasin, M. (2018). Zakat Untuk Mengurangi Angka Ketergantungan Ekonomi Dengan Penyaluran Model Usaha Produktif. INFERENSI: Jurnal Penelitian Sosial Keagamaan, 12(1), 239-258. https://doi.org/10.18326/infsl3.v12i1.239-258

Muhammad, I. (2019). Analysis of Zakat System in High-Income Islamic Countries. The Journal of Muamalat and Islamic Finance Research, 16(2), 1-11. https://doi.org/10.33102/jmifr. v16i2.219

Mustahal, A., \& Kelib, A. (2017). Study Tentang Pemungutan Zakat Penghasilan Pegawai Pada Unit Pengumpul Zakat Kantor Kementerian Agama Kota Salatiga. Jurnal Hukum Khaira Ummah, 12(1), 27-38.

Niam, M. (2016). Hasil Riset: Lembaga Zakat Swasta Lebih Kreatif dan Inovatif. NU Online. http://www.nu.or.id/post/read/72393/ hasil-riset-lembaga-zakat-swasta-lebih-kreatif-dan-inovatif 
Permana, A., \& Baehaqi, A. (2016). Manajemen Pengelolaan Lembaga Amil Zakat Dengan Prinsip Good Governance Agus Permana Ahmad Baehaqi. Al-Masraf(Jurnal Lembaga Keuangan Dan Perbankan), 3(2), 117-131.

Ridwan, M. (2016). Zakat Vs Pajak: Studi Perbandingan Di Beberapa Negara Muslim. ZISWAF : Jurnal Zakat Dan Wakaf, 1(1), 1-22.

Saad, A. Y. Q., \& Foori, A. M. Al. (2020). Zakat and tax: A comparative study in Malaysia. International Journal of Innovation, Creativity and Change, 10(12), 140-151.

Sawmar, A. A., \& Mohammed, M. O. (2019). Governance of Formal Zakat Institution in Saudi Arabia; Issues and Challenges to Improving Zakat Payers' Compliance. International Journal of Zakat, 4(2), 23-40.

Sulistiani, I. (2016). Zakat Internasional. Kompasiana. https://www. kompasiana.com/irasulistiani/5847880364afbd52050263d2/ zakat-internasional

Suprayitno, E., Aslam, M., \& Harun, A. (2017). Zakat and SDGs: Impact Zakat on Human Development in the Five States of Malaysia. International Journal of Zakat, 2(1), 61-69. https:// doi.org/10.37706/ijaz.v2i1.15 